Journal of Jungian Scholarly Studies

Vol. 9, No. 2, 2014

\title{
The Psychology of Terror, American Exceptionalism, and the Greek God Pan
}

\author{
Sukey Fontelieu, Ph.D. \\ Pacifica Graduate Institute
}

This study strives to contribute to a better understanding of contemporary anxieties in American culture by applying meanings derived from mythology to panic inducing cultural phenomena. It asks if the Greek god Pan and his retinue of nymphs metaphorically exemplify an archetypal core within an American cultural anxiety complex. The principal technical device used is Jung's method of amplification, rendering cultural material at a more psychologically substantial level.

This hermeneutic research views primary sources for and commentaries on the terrorist attacks of September 11, 2001 and the American reactions that followed. A faulty belief in American exceptionalism is examined for its contribution to the reactions by the American government and its citizens. Some consequences of American exceptionalism, as seen in reactions to $9 / 11$, are clarified through a correlation with a metaphoric reading of Pan, the Greek nature god. Pan's compulsion into life is considered to be a symbolic expression of an archetype that was once alive in the bold spirit of America, but has rusted into paralysis due to a lack of initiative towards contemporary problems.

It was as if the government of the Unites States, starting at the top, had decided that the terrorist outrages of September 11, 2001, meant that law, custom and decency had all been suspended sine die. (Hodgson, 2009, p. 127)

History ... is a nightmare from which I am trying to awaken.

(Joyce, 1961, p. 34)

American exceptionalism, as described by the French historian Alexis de Tocqueville (1840), is based on the notion that "the position of the Americans is quite exceptional, and it may be believed that no other democratic people will ever be placed in a similar one" (pp. 36-37). Tocqueville echoed earlier voices, such as John Winthrop's sermon on the eve of the Puritan's landing in Massachusetts, "that wee shall be as a Citty upon a Hill, the eies of all people are upon us" (as quoted in Hodgson, 2009, p. 1). Exceptionalism has been reiterated by many other leaders, 


\section{Journal of Jungian Scholarly Studies 2}

including Abraham Lincoln, who envisioned America as "the last best hope of earth" (1862, para. 3) and Barak Obama who stated "America must always lead on the world stage" (2014, para. 25). American exceptionalism can be construed as a nearly inaudible seed syllable within a cultural complex (Singer, 2004; Singer \& Kimbles, 2004), anxious in nature, which formed in the early history of the US and has been triggered by recent events in American history.

American exceptionalism is a core belief based on the notion that America is fundamentally different from other nations because it was formed out of a revolution without an antecedent base in feudalism (Wood, 2011). This inspired a society believing not only in "liberty, equality, [and] constitutionalism ... [but also] a special destiny to lead the world toward liberty and democracy" (pp. 2-3). It carries the belief, birthed in the Puritan faith of the pilgrims, that their purity formed a natural and close alliance with God and this destined the early Americans to be a people chosen to lead others.

This doctrine is still used to guide American policy in the post-9/11 era. The Bush administration invoked a contemporary use of exceptionalism in its response to 9/11. On the evening of the attacks President George W. Bush addressed the nation, describing the US as "the brightest beacon for freedom and opportunity in the world" (2001a, para. 4). In the appeal to the United Nations to legitimize an attack on Iraq in 2003, the US government pressed for the attacks to be sanctioned by declaring that the US must "achieve this essential victory in the war on terror to promote freedom" (Bush, 2003, para. 13). The argument included an explicit right to impose "freedom" onto other peoples (David \& Grondin, 2006). For some in contemporary America there is still a lingering "belief that it is the destiny, some say the God-given destiny, of the United States to spread the benefits of its democratic system and its specific version of capitalism to as many other countries as possible" (Hodgson, 2009, p. 159).

However, the unconscious hubris in exceptionalism has resulted in the US becoming more split off from other peoples. It is a cause of projection onto the nation and causes projection within the US onto others. Further, the combination of a belief in American exceptionalism and recent increases in violence toward Americans have led to overprotective measures as well as a tendency to fall into panic and/or apathy. Perhaps these projections of shadow contents actually increase the likelihood that terrorist assaults on innocents will continue. The application of two of Swiss psychiatrist C. G. Jung's theories, the psychological functions of myth (Jung, 1951/1959a [CW 9i]) and the formation of complexes in the psyche (1948/1960 [CW 8]) when combined with the recent addition of cultural complex theory, first envisioned by Jungian analysts Thomas Singer and Samuel Kimbles (2004), may lead to a better understanding of these tendencies.

Cultural complex theory is rooted in Jung's theory of complexes in individuals in which he explores the dynamics of shadow material in the unconscious 


\section{Fontelieu}

$(1948 / 1960$ [CW 8]). An event or series of events precipitates a traumatic reaction, which leads to a regression, and consequently efforts are made to protect from further wounding. The traumatized "splinter psyche" (p. 98 [para. 204]), or complex, fails to thrive and becomes cut off from mediating influences because it is emotionally over-reactive, tends to see all facts as reinforcing its beliefs, interprets efforts to initiate change as threats, and has a "remarkable degree of autonomy" over the ego (p. 99 [para. 205]).

Jung acknowledged that he could not fill in "this incomplete picture" (1948/1960, p. 104 [para. 219]) and post-Jungians have subsequently added to the discourse. I will only mention Jungian analyst John Perry (1970) for conceiving of "the entire psyche as structured not only in complexes, but in their bipolar systems or arrangements" (para. 38), consisting of a protective shell and a core, which "is derived from one or more archetypes" (Samuels, Shorter, \& Plaut, 2005, p. 34) and Singer and Kimbles applications of Jung's theory of complexes to the dynamics of groups (2004).

Methodological concern regarding the application of depth perspectives to studies of culture, the traditional field of social scientists, require care and attention. Violence in American culture has been studied from a number of sociocultural perspectives, such as terror management theory (Barak, 2005), social disorganization theory (Cohen, D. 1998), and grounded theory (Moustakas, 1994). These evidence-based research methods have aptly framed pertinent questions concerning anxieties about violence in the United States and have provided useful data. There is currently a trove of data available that supports and helps to facilitate the application of a depth perspective to considerations about cultural anxieties.

Recognition of the value of studying a culture psychologically through the application of myth is not new (Erikson, 1994; Jung, 1946/1978), nor are methodological concerns relating to such studies ( $\mathrm{Lu}, 2013)$. Certain criteria are essential when using complex theory with groups. As Jungian historian Kevin $\mathrm{Lu}$ (2013) warns, the theorist needs to guard against reductionism and essentialism, and he points to the necessity for and challenges to adhering to the standards of both historical and depth psychological research in an interdisciplinary study such as this.

It is doubtful whether any two people in a given culture would always agree about all societal standards, let alone what symbolic material and patterns accurately map the culture. There is nothing one could say that would be true of all Americans all the time, but there are some things one can say about political and social trends and their unconscious underpinnings. A "culture is not monolithic and can contain incompatible elements, and ... different cultures will have things in common" (Jahoda, 2012, p. 295). It is as critical not to stereotype Americans as it is essential to avoid seeing a person as the sum of his or her DSM-5 diagnoses (i.e., "a borderline"). 


\section{Journal of Jungian Scholarly Studies 4}

Diversity exists not only between cultures but also within cultures. Nevertheless, within the loosely held perimeters of a culture, the values and "conditioning elements" (Kroeber \& Kluckhorn, 1952, p. 181) influence behaviors in many ways. Some of the ways a culture conditions people are unconscious and so a fuller understanding of the behaviors of a society may be gained through an exploration of the collective unconscious in a group.

In groups there are issues, such as racial bias, that tend to resist transformation. Laws change slowly, but not compared with the saturnine pace of societal biases and prejudices. Like people, cultures that do not examine their anxieties will tend to project their blind spots onto other cultures. When shadow material (the unconscious content in a complex) is exposed, it may erupt, revolutionize, instigate regression, or promote compassionate dialogues. Regardless of how these shadow elements are expressed in consciousness, they could be understood as a compensatory move by the unconscious to restore wholeness (Jung, 1946/1978 $[C W 10])$.

Cultural complexes are formed out of fear-based oppositions to other social groups (Kimbles, 2003), and then polarize the psychic energy field of the group they fear. The polarization creates a strong potential for an opposing complex to form in the projected-upon group and leads to a rigid dichotomy between the unconscious of the two groups. The metaphor I use to envision this idea is the mechanistic revolving and interlocking of gears. Each gear is a spinning wheel with teeth, or cogs, that all together create a force that moves a corresponding cog in an adjoining wheel. The cogwheels are enmeshed and dependent on each other for motion and speed. Such a mechanistic arrangement moves parts in a rigid lockstep. Once the gears are in motion, minimal effort is needed to keep the process going, and there is no possibility for change. When one group in a culture negatively projects its unconscious fantasies onto another group the projections are then mirrored back and a process, like a cogwheel, is set in motion. Projection dangerously reinforces ethnocentric antagonism between groups and promotes the spread of negative cultural complexes.

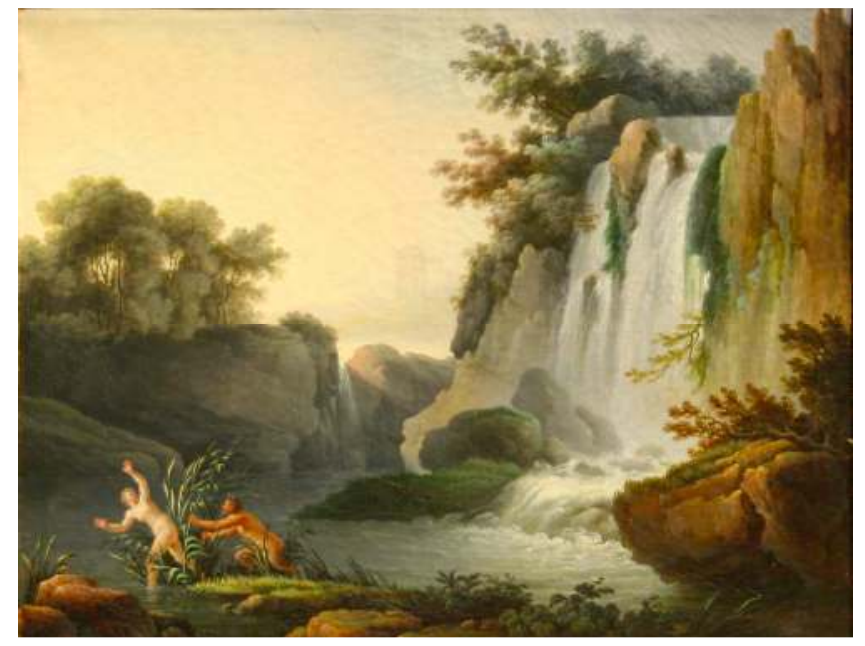

Figure 1. Pan et Syrinx, Lavinia Fontana, 1891, Musee des Beaux-Arts de Marseille. In the public domain. 


\section{Fontelieu}

\section{Pan as Archetypal Core in an American Complex}

To the ancient Greeks, Pan was a diviner, protector of the wild, bringer of terror and panic, provider of sustenance for his cult, and pharmakos. He was also a trusted war ally to his friends and the carrier of the instinctive life force of fertility (Borgeaud, 1979/1988; Boardman, 1997). Pan's compulsion into life is the prominent aspect of his archetypal energy and is often represented by his aggressive chasing after the nymphs. The nymphs were found in all the beautiful places in nature. There were countless nymphs, who lived as long as the tree she lived in grew or the river that was her home ran (Larson, 2001). They were always female and cared for others in roles such as nurses, midwifes, or guardians.

In one myth, craving the nymph Syrinx's attention, Pan burst into the peace of the piney banks of Arcadia's Ladon River and chased her into the reeds (Ovid, 1955/1986). The pastoral peace was destroyed. Syrinx was cornered by Pan and chose metamorphosis rather than surrender and was transformed into the reeds (Tatius, 1917/1969). Pan, in tears, gathered up the reeds, his breath filled them and the music of the panpipes was born out of his frustration and grief.

Pan's pursuit of Syrinx exemplified the pattern of Pan's single-minded pursuit of his desires without concern for the consequences for others. At other times Pan is protective, but here he destroys innocence. A recurrent theme in Pan's myths with the nymphs is that innocence requires protection to exist and when left unprotected devolves into a lesser state of consciousness. This is an apt metaphor for the shadow side of the dogma of exceptionalism in America.

When viewed impartially, one could say that when America formed as a nation it too burst onto a bucolic landscape. The Native American cultures that were already well established were chased into submission, more and more brutally as the nation spread west (Meyer, 2005). The stories of America's birth as a nation focus on the courage and ingenuity it took to establish a continental United States, rather than on the costs to others. As Jung points out in his considerations of Nazi Germany, when a one sided attitude, such as that of Pan or the early colonists, takes hold a compensatory function is an inevitable outcome (1946/1978, p. 222 [CW 10, para. 453]). The progress American exceptionalism justified ignored the autonomy of innocent peoples, just as Pan's aggressive self-interest destroyed the bucolic peace of Arcadia.

The landscape of Pan's isolated wilderness in Arcadia, which he shared with the nymphs and which was a favorite location for Roman rural idylls, has much in common with the American dream of a land of wild frontiers and a bucolic land of "milk and honey." The idea of a spacious and beautiful pastoral land, well protected by natural isolation and a self-sustaining terrain, is a central characteristic in the Pan myths (Borgeaud, 1979/1988) as well as in many legends and tales that shape the national character of the United States (Guthrie, 2011; Smith, 2011). 


\section{Journal of Jungian Scholarly Studies 6}

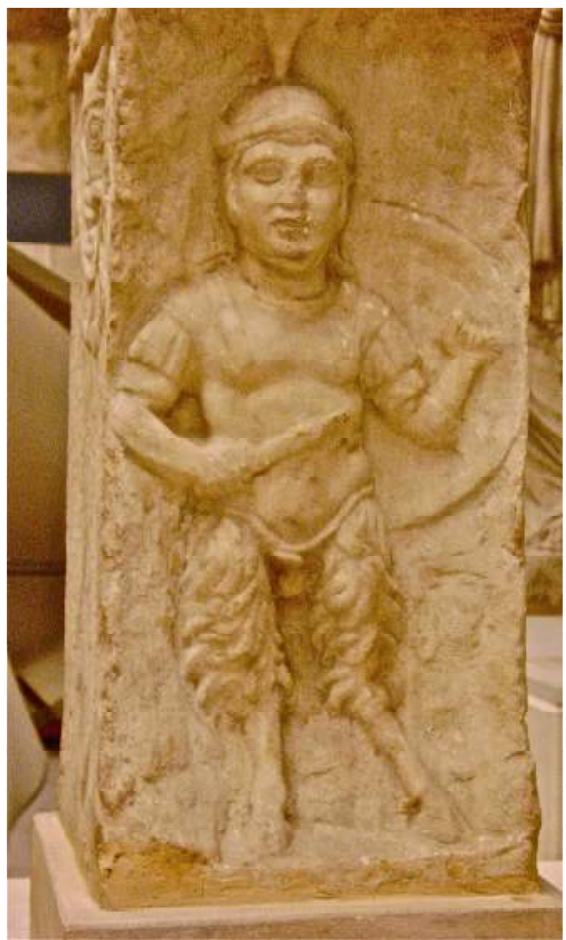

Figure 2. Marble altar: Pan, a rustic deity with goat legs, shown in armor. Roman, $1^{\text {st }}$ $\mathrm{CE}-2^{\text {nd }} \mathrm{CE}$ (probably). (C) Trustees of the British Museum.

Pan has as many battle myths as he does myths in which he is chasing after nymphs. These are less well remembered. He fought with Hermes to help Zeus gain power over the Titans (Kerenyi, 1996), was a general in Dionysus's army in India (Polyaenus, 1994), came to the rescue of Athens at the Battle of Marathon (Pausanias, 1961), and aided the Athenians in routing a Gallic army (Herodotus, 1921/1960). Pan's method was to infect the enemy with fear. For example, Polyaenus (1994) (born c. $100 \mathrm{CE}$ in Bithynia), a rhetorician and author of Stratagems of War, recounted the myth of Pan's chaotic use of echoes while a general in service to Dionysus in India:

Dionysus' [lost text] was in a hollow valley, when the scouts reported that an enemy band of 10,000 was camped against them. Dionysus was afraid, but not Pan, who at night signaled Dionysus' army to give their loudest yell. They shouted, and the rocks resounded and the hollow made the noise seem to the enemy to be that of a much greater force. Struck by fear, they fled. To honor 


\section{Fontelieu}

Pan's stratagem we call Echo "friend of Pan," and we name the groundless fears that strike armies at night "panic.” (p. 17 [1.2])

America's battle slogan for the start of the Iraq War in 2003, "Shock and Awe," would have been well suited to Pan's battle strategy, which was to outsmart the enemy by instilling fear in their hearts and to win victories for his allies without causing them casualties. Many of Pan's traits, he was a warrior and a hypermasculine hunter in his relationships with the nymphs, correspond to other modern cultures, and a case can be made for a great deal of global unconsciousness sourcing back to his archetypal domain, but the present discussion is limited to the US and terrorism. Pan's archetypal framework emphasizes the fear that an overpowering force, such as that of the US military, engenders (Sipri, 2014). The following comparison of the attack on 9/11 and the myths of Pan outlines several parallels in the ways in which the American culture has shifted its course towards a fear-based culture.

\section{9/11}

On September 11, 2001 a multipronged, suicidal terrorist attack using airplanes filled with ordinary passengers felled the Twin Towers of the World Trade Center in New York City and crippled the Pentagon in Washington, DC, killing nearly 3,000 people. Americans woke that autumn day in the general state of complacency to which they had become accustomed (Colvin, 2001; Irish, 2002), but once the disbelief wore off, that complacency rapidly morphed into fear (Pyszczynski, Solomon, \& Greenberg, 2003, pp. 4-6). The confusion and a feardriven mob mentality prompted many in the culture to mutely accept the government's choices both to go to war and to quickly adopt protective measures, such as the USA Patriot Act, which curtailed personal freedom. In the parlance of cultural complex theory, the trauma of 9/11 triggered a latent complex, and the government began to act as a shield or protector while the majority of the culture grouped together for a time and obediently bunkered down.

Two months later, PTSD was diagnosed in 20 percent of New Yorkers living near the WTC (Galea, Ahern, Resnick, Kilpatrick, Bucuvalas, Gold, et al., 2002). This is considerably higher than the 3.6 percent of New Yorkers suffering from symptoms of PTSD the year before the attack (Cohen, Kasen, Chen, Gordon, Berenson, Brook \& White, 2006). Following the attacks, PTSD symptoms were diagnosed in one in ten of New York City residents (Marshall \& Galea, 2004; Osborn, Johnson, \& Fisher, 2006). In general, PTSD and panic-based reactions are unfortunate by-products of war. However, the US was not at war, making the attacks psychologically as well as literally come from "out of the blue" (American Psychiatric Association, 2013, p. 209), like Pan, the god of panic, bursting into the bucolic landscape and creating confusion and terror. 


\section{Journal of Jungian Scholarly Studies 8}

One of Pan's epithets is Pan Phorbas, the terrifying one. Pan is associated with panic and all its legion of psychological burdens (Boardman, 1997), which Pan infects, using cunning and surprise, into his enemies. Panic disorder, is a "disorder," or an infection of the psyche, with mythological roots in Pan's myths.

The Greek geographer (c. 110 CE-180 CE) Pausanias (1935/1981) reported a battle between the Greeks and the Gauls when during the night a panic fell on the Gauls:

For causeless terrors are said to come from the god Pan. It was when evening was turning to night that the confusion fell on the army and at first only a few became mad, and these imagined that they heard the trampling of horses at a gallop, and the attack of advancing enemies; but after a little time the delusion spread to all. So rushing to arms they divided into two parties, killing and being killed, neither understanding their mother tongue nor recognizing one another's forms or the shape of their shields. Both parties alike under the present delusion thought that their opponents were Greek, men and armour, and that the language they spoke was Greek, so that a great mutual slaughter was wrought among the Gauls by the madness sent by the god. (p. 503 [VIII, xxiii, 6-9])

The mythic motif of "causeless terrors" bringing panic and madness in the night to the enemies of Pan echoes the description of Panic Disorder in the Diagnostic and Statistical Manual of Mental Disorders (APA, 2013), the standard for diagnosing mental disorders in the United States ${ }^{1}$. A panic attack is defined as an "abrupt surge of intense fear or discomfort" (APA, 2013, p. 214). Symptoms include a pounding heart, sweating, trembling, sensations of shortness of breath or choking, nausea, feelings of chest pain, dizziness, derealization (feelings of unreality) or depersonalization (being detached from oneself), and fears of "going crazy" or losing control (p. 214). The diagnosis of panic disorder is given when an unexpected state of panic occurs more than once. "Unexpected refers to a panic attack for which there is no obvious cue or trigger at the time of occurrence- that is, the attack appears to occur from out of the blue, such as when the individual is relaxing" (p. 209). These symptoms are apt descriptors for the reactions to Pan by the Gauls. They were confused, felt they were going mad, and lost control.

Eyewitness examples of the panic and terror on 9/11 include the following:

When we got to about 50 feet from the South Tower, we heard the most eerie sound that you would ever hear. A high-pitched noise and a popping noise made everyone stop. We all looked up. At th[at] point, it all let go. The way I see it, it had to be the rivets. The building let go. There was an explosion and the whole top leaned toward us and started coming down. 


\section{Fontelieu}

I stood there for a second in total awe, and then said, "What the F_ ? I I honestly thought it was Hollywood [Jeff Birnbaum recounts his experience]. (Lucy, 2003, para. 11-12)

You have two 110 story office buildings. You don't find a desk. You don't find a chair. You don't find a telephone, a computer. The biggest piece of a telephone I found was half of a keypad, and it was about this big: (makes a shape with his hand about 4 inches in diameter). The building collapsed to dust [Description of what New York Fire Fighter Joe Casaliggi found in the rubble at the WTC]. (Cassaliggi, 2013)

Just as the surreal images of the airplanes, the sound of the exploding rivets, and then the overwhelming destruction disoriented the first responders, the sound of an approaching noisy, monstrous Pan created "madness" and led his enemies to panic and to run in disarray (Polyaenus, 1994). Pan forcefully dominated his landscape and is an archetypal representation of the impulse to impose oneself upon others with, as classicist Lewis Farnell (1909/1971) describes him, "rustic and uncouth" powers (p. 431). Terrorism, like the idea of Pan, creates fear.

The US has traditionally avoided the fearful side of Pan/terrorism and had become accustomed to being in control on the world stage due to its considerable military presence, most famously turning the tides in World War's I and II. On 9/11, however, the roles were reversed. Terrorists set a trap that was "suddenly and unexpectedly sprung" (Segal, 1969, p. 18). Thus, radical Islam dramatically imposed its presence, delivering in those airplane/bombs pain, anger, and fear to the American psyche. America responded with overprotective measures, scapegoating, and a childlike naiveté in the general public.

Identifying radical Islamists, the American people, or any other group, as the "Pan element," or thinking in terms of labeling one group as being Pan-like and another as nymph-like oversimplifies the archetypal and moves toward the stereotypical. Rather than freezing up the fluidity inherent in the archetypal with yet another set of labels, the objective here is to determine whether the structuring of some events in modernity are reflective of the structuring in Pan's myths and how might this be instructive.

The US response to the attacks was immediate and dramatic. On September $11^{\text {th }}$ President George W. Bush's first directive to his chiefs of staff was that "Everything is available for the pursuit of this war" (Clarke, 2004, p. 24). On the evening of September $11^{\text {th }}$ Bush addressed the nation and employed exceptionalism in his rhetoric: "America was targeted for attack because we're the brightest beacon for freedom and opportunity in the world. And no one will keep that light from shining... We will make no distinction between the terrorists who committed these acts and those who harbor them" (2001a, para. 4, 9). A line was clearly drawn between "the brightest beacon" and the terrorists. But this enemy added new 


\section{Journal of Jungian Scholarly Studies 10}

dimensions to war because it has no borders, no nation, and no adherence to the "rules of engagement" (Lifton, 2003). Bush was trying to define the perimeters of the war. He had the unfortunate task of trying to corral quicksilver, as al-Qaeda, the suspect at that point, was well adapted to splitting apart and reforming seemingly invisibly.

The next day Bush and Secretary of Defense Donald Rumsfeld asked for an investigation into Iraq's complicity with al-Qaeda (Clarke, 2004, p. 30; Lifton, 2003, p. 9). All hesitations, and there were many even within the White House and Pentagon, were aggressively swept aside (Clarke, 2004; Woodward, 2004). A plan based on fighting wars in "multiple, simultaneous major theaters" (David \& Grondin, 2006, p. 39) was immediately implemented. This plan had been drawn up in 2000, before the attacks, a tactic justified only by assuming that the US is entitled to convert the world to democracy. It was titled, "Rebuilding America's Defenses: Strategies, Forces, and Resources for a New Century" (David \& Grondin, 2006) and called for military forces to

defend the American homeland; fight and decisively win multiple, simultaneous major theater wars; perform the "constabulary" duties associated with shaping the security environment in critical regions; transform U.S. forces to exploit the "revolution in military affairs." (p. 393)

Following the attacks, martial justice was encouraged by Bush's speeches: "This crusade, this war on terrorism" with these terrorists, who are "barbaric ... [and] a new kind of evil" (2001b). This verbal prologue led the country into long, protracted battles. From the start the anger of the governing voices encouraged war as the patriotic answer. Rather than a calming influence, the government inflamed the fear and reactivity understandably being felt by many Americans at the time.

Pan's myths parallel such brutal reactivity and self-interest. In the third century BCE the poet Theocritus explained that "he's one o' the tetchy sort; his nostril's ever sour wrath's abiding-place" (Edmonds, trans., 1912/1977, p. 11 [I. 16-20]). Roman poet Valerius Flaccus wrote "Sport it is to the god [Pan] when he ravishes the trembling flock from their pens, and the steers trample the thickets in their flight" (1934/1963, p. 131 [III. 46-57]). He could be vengeful. When spurned by Echo he raged against her and "in a desperate fury, like so many dogs and wolves, tore her all to pieces and flung about them all over the earth her yet singing limbs" (Longus, 1916/ 1978, p. 163 [III. 23]). Pan is like the US in that he is a rescuer to his allies, but for his enemies, his methods of imposing his will is overwhelming and oppressive.

Pan's mythic motifs mirror both an underlying inflation and a fear-based apocalyptic vision in the US, which has developed out of America's superpower status in the world (Lifton, 2003). American psychiatrist Robert Jay Lifton interpreted the plan to make the world "safe for democracy" as a messianic 


\section{Fontelieu}

message and sees modernity as caught in a "worldwide epidemic of violence aimed at massive destruction in the service of various visions of purification and renewal" (p. 1). He understands an apocalyptic vision as an impulse to destroy the world as it is, with the idealistic belief that by doing so the world will be purified (pp. 4-5). The tactics such a vision legitimizes include scapegoating and manipulation of the mainstream public through the use of euphemisms and co-opting of sentiments, as well as brutality toward the perceived enemy, all in service to a better future.

An apocalyptic vision naturally includes the ideal of a golden era, like the bucolic Arcadia of the poets (Ovid, 1955/1986; Theocritus, 1999), which is now to be restored by the believers through purification (Lifton, 2003, p. 78). It is a “response to one's enemy's pursuit of absolute purification, [and so] one seeks to purify absolutely in turn; in the name of destroying evil, each side seeks to destroy not only the other but enough of the world to achieve mystical rebirth" (p. 39).

Pan signifies underlying aggression in the pursuit of a world made safe for one's own, but not for all, regardless of the effect on the innocent. American leadership harnessed a Pan-like brutality, arrogant and self-serving, out of the protective feelings and prevailing sense of outrage in the nation. The government exploited the public's fear to achieve its own goals. Attacking Iraq was an opening for the planned overthrow of its government, with Iran, and North Korea on the list (Clarke, 2004). Bush (2002) identified these nations as the "axis of evil." As long as they could be defined as "the terrorists who committed these acts and those who harbor them" they were fair game in a preventive, multi-theater, global war to promote democracy (Bush, 2001a).

In the months following 9/11, perceptions in America rapidly compounded to try to relieve the anxiety created by the "monstrous" (Venn, 2002, p. 121) acts by countering them with an overwhelming show of strength and willingness to do violence (p. 124). Bush sought to legitimize the political ideology, known as the Bush Doctrine, that the US has a duty to keep the world free for democracy.

The Bush administration defends its pursuit of this unlikely goal by means of internationally illegal, unilateralist, and preemptive attacks on other countries, accompanied by arbitrary imprisonments and the practice of torture, and by making the claim that the United States possesses an exceptional status among nations that confers upon it special international responsibilities, and exceptional privileges in meeting those responsibilities. (Pfaff, 2007)

American exceptionalism was being used as justification to attempt, in effect, to create an American empire by spreading democracy (David \& Grondin, 2006).

As a bold general willing to advance ingenious ideas, Pan's inflated self-worth served him. It allowed him to disregard the pain and fear of the nymphs. In other 


\section{Journal of Jungian Scholarly Studies 12}

circumstances it brought him the contempt of others. He had the "temerity to compare his music with that of Apollo, and to challenge the god of the lyre to a trial of skill" (Bulfinch, 1855, pp. 70-71). Of course, he and his panpipes lost, which speaks to his grandiose sense of self: he fancied himself a better musician than the god of music. Hubris like Pan's can be seen in the American ideology that allows for the smug belief that it has "a special destiny to lead the world toward liberty and democracy” (Wood, 2011, p. 3).

Though America is not alone in having political policy driven by hubris, it is quick to claim a top status. If exceptionalism is a component of a cultural complex and the projections of this complex are focused on other cultures, then it should not surprise Americans that other cultures, even among allies such as England and Australia, disparage the US "because of suspicions that its true goals are domination and exploitation rather than the promotion of human rights and liberty" (Glick, et al., 2006, p. 372). The same study found significant levels of contempt rather than admiration or envy toward the US (Glick, et al.). Others while would prefer to annihilate it altogether (Aaron, 2008).

Exceptionalism parallels the inflated radical Islamist belief that they are destined to "seek the destruction of Western democracy and the conversion of the world to their concept of Islam" (Aaron, 2008, p. 1). Radical Islamists vow to lead the world out of the impurities of secularism and into a new world birthed out of a revolution (2008). This perceived impurity in the west then justifies destroying the "corrupt" world through jihadist acts of terror (2008). Pan's explosive attacks and myopic objectification of the other's value based on their availability to fulfill his needs are reflected in mythic-sized dreams of grandiosity in American and radical Islamist ideologies. They mirror each other.

Jungian analyst Murray Stein (1995) stated that Jung

felt deeply that fanatical ideologies of any sort were demonic because they depended for their existence upon identification with archetypal images and upon grandiose inflations, which crippled individual accountability and destroyed moral consciousness. Such ideologies should therefore be confronted by psychological interpretation, which would have the benefit, if successful, of restoring consciousness to its proper dimensions. (p. 20)

Understanding that there is a dynamic way in which unconscious complexes infect other cultures could be a first step toward developing understanding, tolerance, and better communication between sides. 


\section{Fontelieu}

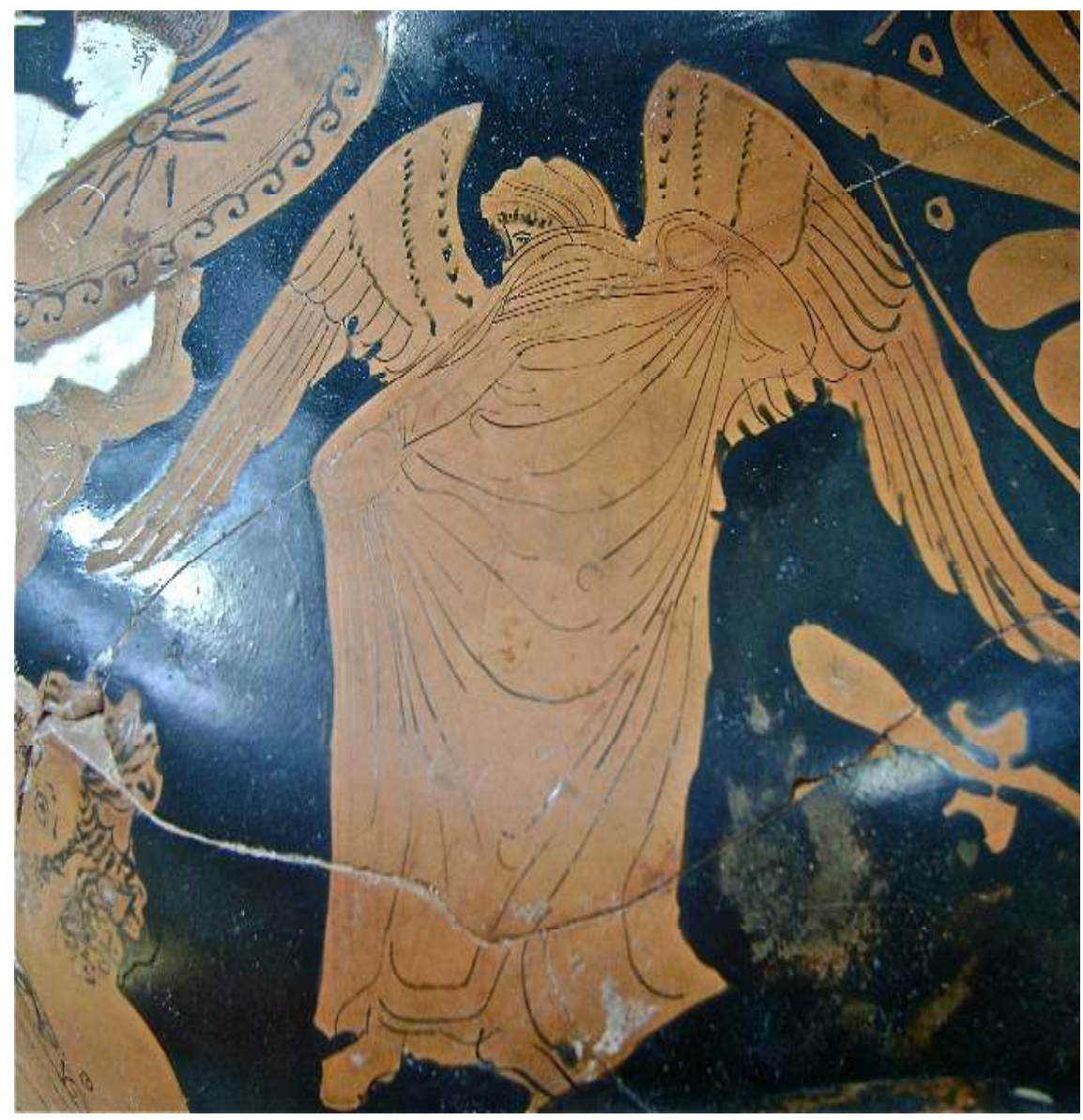

Figure 3. Echo hiding from Pan. Attic Red Figure. 370 BCE—-350 BCE. British Museum: London, England. (C) Trustees of the British Museum.

In myth, Pan chases a nymph, out of fear she asks for help, and is metamorphosed. She is still alive but in a vegetative form, transformed by the interaction. She devolves into a part of the landscape without the power of volition or a voice of her own. Explosions of Pan power are followed by torpor and despair in the nymphs. This same pattern developed after the attacks. The majority of the American public passively accepted political decisions with immense consequences. It would appear that a compensatory naiveté in the American public aided in the formation of post-9/11 protective visions in the US and that like the nymphs, the panicky state Americans found themselves in following the attacks led to a regression into consuming and escapism.

One response to $9 / 11$ was the federal government's choice to implement a course of action to keep people focused on consuming as a way to relieve anxiety (Arndt, Solomon, Kasser, \& Sheldon, 2004). This agenda was initiated in Bush's 


\section{Journal of Jungian Scholarly Studies 14}

first hours after the attack when he told his aids "I want the economy back, open for business right away" (Clarke, 2004, p. 24). Ten days after the attack Bush encouraged the public to "Get down to Disney World in Florida. Take your families and enjoy life the way we want it to be enjoyed" (Bush, 2001c).

The American public escaped into distraction enough to effect the statistical terrain. "Americans bought homes and cars in record quantities. They also snapped up appliances, furniture, and electronic gadgets. From October through December, consumption soared at a 6\% annual rate" (Zuckerman, 2002). They worked hard at losing themselves. "People went to enormous lengths to distract themselves from the tragedy — by drinking, gambling, renting videos, watching television, and shopping" (Pyszczynski et al., 2003).

After the explosive attacks the need to feel safe overwhelmed the public, which enabled "unquestioning willingness to accept whatever the leadership said was necessary to fight terrorism" (Clarke, 2004, p. 1). Many citizens of the US, shocked and in fear that another strike was imminent, responded as the nymphs did when overwhelmed by Pan and froze, passively allowing the government to move forward with preplanned aggression, regardless of the loss of freedoms for the public (2004). Safety, it can be argued, replaced freedom as a pillar of American decision-making.

Bush told the country, "The world has changed because we are no longer safe" (2001c). The search to restore a lost sense of security aided the creation of US government policies such as the USA Patriot Act of 2001 (FinCEN, 2012), HIPPA standards for privacy (Health Information Privacy, 2012), and zero tolerance standards at public schools (Zero tolerance, 2012). The anxiety most Americans naturally felt was exploited to drive policy. The safety that was once a given became something hoped to be restored through policy-making.

Meanwhile, euphemisms began to spring up like weeds. Although the relanguaging of the "war on terrorism" often began inside Washington's beltway, the euphemisms usually came into common usage when "embedded" in the mainstream media (Slovenko, 2005). The euphemisms obfuscated the brutal reality of distant battles for the American public and reflected the "unconscious tendency to make the autonomy of the complex unreal by giving it a different name" (Jung, 1948/1960, p. 99 [CW 8, para. 206]). Acting as an aggressor was called making a "pre-emptive strike," and a "surgical strike" was the term used for bombing city streets. Friendly fire and waterboarding speak for themselves. Collateral damage meant dead people ${ }^{2}$. Ralph Slovenko, a psychiatrist, plays with the sanitization of initializing Weapons of Mass Destruction: "Euphemisms that mislead or deceive are known as doublespeak (or we might say, WMD — words of mass deception)" (2005, p. 533). The American public swallowed the experts' euphemisms and remained numb to the loss of innocent lives that were a consequence of Bush's war on terror. 


\section{Fontelieu}

Conversely, during the weeks and months immediately following the attacks, experts began to express beliefs essentially geared to keep the anxiety about personal safety alive. They rhetorically kept the public in a state of fear and near panic. "Today's terrorist can strike at any place, at any time, and with virtually any weapon" (Office of Homeland Security, 2002, p. 1).For a short period "unknown unknowns" were suddenly objects of concern (Furedi, 2007). An unknown unknown, an outcome that a planner could not conceive of while determining a course of action, became a news talk show item after Rumsfeld (2006) repeatedly made statements such as, "There are unknown unknowns - there are things we do not know we do not know" about the Islamist radicals. After the news of the attack broke on television and internet news sites, the message was established that the chance of another attack was possible; what was possible quickly became probable and from there morphed into inevitable (Furedi, 2007).

The rhetoric engendered by the government, and repeated in the media, and the fearful state of many Americans resulted in a projection of evil onto many Arab Americans and Muslims and a disregard for their civil rights. Kimbles (2003) states that when fear becomes the primary affect that organizes a culture's reactions to an event it can lead to scapegoating. One consequence of the Patriot Act has been widespread abuse of suspected terrorists in the US.

Jonathan Turley, a professor of national security and constitutional law at George Washington University... an expert in prison law, said in an interview on Friday that the use of the dogs to frighten detainees in the New Jersey jail underscored "the trickle-down effect" of the disregard for immigrants' civil rights that top government officials showed after 9/11. "It trickled down through military intelligence, through low-level personnel and to sheriffs," he said. "Suddenly people who were predisposed to the use of such harsh measures thought they had license to use them, and 9/11 gave them a great appetite." (Bernstein, 2006, para. 6-7)

As Pan's presence caused a "sudden confusion and consternation of a crowd" (Plutarch, 1936/2003, p. 37 [356, D]), after 9/11 the country was infected by a mob mentality. In an anxious or even panicked state it is easier to be led into believing things one would not otherwise accept as true. Jung spoke about this in his writing on participation mystique:

Practical experience shows us again and again that any prolonged preoccupation with an unknown object acts as an almost irresistible bait for the unconscious to project itself into the unknown nature of the object and to accept the resultant perception, and the interpretation deduced from it, as objective. (1948/1967, p. 204 [CW 13, para. 252]) 


\section{Journal of Jungian Scholarly Studies 16}

The mob psychology curdled into a climate of hate in the US. "Something about the current state of America has been causing far more disturbed people than before to act out their illness by threatening, or actually engaging in, political violence" (Krugman, 2011, p. A19). Arab Americans were targeted as scapegoats. With no evidence of any connection to terrorism, hundreds of Muslim, Arab, and South Asian men were rounded up on the basis of racial and religious profiling and subjected to unlawful detention and abuse. Scapegoating resulted in "widespread labeling of opponents of the war, or even those insufficiently enthusiastic about it, as 'unpatriotic,' 'un-American,' 'traitors,' or if they were in foreign countries, 'anti-American' and 'enemies of America'” (Lifton, 2003, p. xi). Scapegoating also led to the suspension of rights and torturing of imprisoned, suspected terrorists at Guantanamo Bay Naval Base, Abu Ghraib prison, and other locations (Kugler \& Cooper, 2010), and to racial profiling of Muslims (Shahshahani, 2011; Swiney, 2006). As von Hippel (2002) concludes regarding the reactions to $9 / 11$, "Humiliation can in itself cause increased levels of commitment and recruitment to 'the cause." An unconscious projection of the humiliation many American's felt in the wake of the attacks appears to have helped fuel even more hatred.

Bush advocated for war in Iraq as well as Afghanistan by attempting to justify pre-emptive self-defense as grounds for war in the modern era (World Press Review, 2012, para. 7-8). He took this argument to the United Nations. When UN General Secretary Kofi Annan was asked if the invasion was legal he stated, "I have indicated it was not in conformity with the UN charter from our point of view, from the charter point of view, it was illegal" (BBC News, 2004, para. 9). Bush charged ahead undeterred.

On March 20, 2003 the US Government led an attack on Iraq using the ad slogan — "shock and awe" with "fear" as the target emotion, betting that character assassination of those who disagreed with the war and the firepower would spread the right messages at home and abroad .... In fear-based decision making, alliances, standards of conduct, and, indeed, common sense go out the window. Whether the opponent is a congressional candidate or an international terrorist, the idea is shoot him before he shoots you. (Richey \& Feldmann, 2003)

This attitude is a mirror image of al-Qaeda leader Osama bin Laden's equally inflated attitude. Bin Laden mocked the US in a videotaped message in 2004: it is "easy for us to provoke and bait .... All that we have to do is to send two mujahidin .... to raise a piece of cloth on which is written al Qaeda in order to make the generals race there to cause America to suffer human, economic, and political losses" (as quoted in Mueller, 2005).

Bush taunted the enemy, "Bring them on" (as quoted in Moore, 2002). "We will make no distinction between the terrorists who committed these acts and those 


\section{Fontelieu}

who harbor them" (Bush, 2001a, para. 9). "I don't care what the international lawyers say, we are going to kick some ass" (Bush as quoted in Clarke, 2004, p. 24). Others in the government promoted fear mongering. "It's only a matter of time before they bomb US cities" (Rumsfeld as quoted in Moore, 2002). The government used the anxiety in the country in the same way the radical Islamists used it. Both sides express beliefs to keep the anxiety alive, and for both the control of the narrative is a component of the warfare.

One "shocks and awes" while the other "provokes and baits." Apparently the two sides are blind to their similarities. As Jung said, one meets one's projections (1951/1959b). "Projections change the world into a replica of one's own unknown face" (p. 9 [CW 9ii, para. 17]). Projection is driving both sides of the conflicts, while blinding both to their similarities. But "arrogance and stupidity are selfdefeating, eventually" (Richey \& Feldmann, 2003). America's self-image as protector of the weak has blinded many in the country to the projection of shadow onto other cultures. In the aftermath of $9 / 11$, the manipulation by both sides aptly fits Jungian analyst Joseph Henderson's (1984) description of the workings of the cultural unconscious as a place of "mutual projection of unconscious factors" (p. 11).

A principle objective of terrorism is to destroy and this can be achieved psychologically by instilling fear in the imagination of one's enemies to destroy their peace of mind. Once the imagination of the country absorbed that a suicide bomber is more invincible than a tower, terrorists succeeded in seizing more power and control over the west than ever before (Clarke \& Newman, 2006, p. 56). Through the media's reporting of the goading and threats, and with only occasional, unpredictable strikes, terrorism has succeeded in making Americans feel unsafe wherever they are (Glick et al., 2006, p. 364). Pan's strategy to overcome his enemies by triggering their own fears parallels this era of uneasiness and instability that now grows in the American landscape.

\section{Conclusions and Some Thoughts about Transformation}

Pan was alive in the imagination of the ancients long before his image as a split god came into being. "Not until the beginning of the fifth century BCE, and after the introduction of his cult in Athens, does the image of Pan take shape" (Eliade, 1987, p. 160). There are no extant statues of Arcadian Pan. Athenian Pan's lower half is envisioned as goat-like, with hairy haunches, cloven hoofs, and a tail (Hillman, 1988), but from the waist up he looks like a man with horns. Pan's myths and functions echoed these opposites. In Pan, the ancients worshipped the divine in the animal and the animal in the divine. The boundary between these opposites was internal and so naturally fluid and flexible.

These two sides of Pan are commonly interpreted reductively so that he is called a split god (Farnell, 1909/1971). This projection of splitting onto Pan is a 


\section{Journal of Jungian Scholarly Studies 18}

modern interpretation and thus more informative about modernity than about Pan because it indicates an oversimplification of a complex issue. Just because Pan is animal and divine does not mean he represented the dichotomy of a simple duality.

Pan embodies a forgotten link to the fluid way the ancients understood a connection between the aggressive instincts in humans and their innate divinity. Failure to understand this, the myths tell us, leads to traumatized reactions; a recurring coil of dread, panic, terror, and subsequent paralysis, which is then followed by further aggression. Going numb and running or ignoring the link between the animal and the divine in oneself, the myths indicate, leads to becoming a part of the landscape in one's own story or to an arrogant disregard for the needs of others.

Pan and the nymphs personify dangerous aspects of splitting caused by trauma. This sort of splitting, birthed in faulty notions such as exceptionalism, has resulted in a complex forming in the culture within which the vulnerable try to hide in apathy, shopping, and entertainment. This is where the shadow side of exceptionalism leads.

Accepting the animal in the divine and the divinity in the animal avoids the trauma of splitting. This suggests a psychospiritual answer is what is called for in these troubled times for America. Perhaps the myths of Pan have some instruction on how to do this. The nymphs cooled Pan's hypermasculine heat. They soothed him and helped him relax (Philostratus, 1931/1960). When Pan was not on the hunt, the nymphs were safe with him, he was their protector and they were his "dear nymphs" (Aristophanes, 2000, p. 579 [978-981]), able to get away with playing tricks on him. As a group, the nymphs were able to ensnare and subdue Pan's lusty and overly aggressive nature, but when alone the nymphs were less equipped to match Pan's power and resorted to self-destructive measures to escape him.

Night after night Pan led the nymphs in labyrinthine dances, where each followed all as the steps would flow from one rhythm to another. "Pan is not only the insistent lover in hot pursuit of the nymphs. He is also their faithful companion (opados), their guide (hegetor) who leads them in dance on the flowery or wooded meadows, and who accompanies their rounds with his pipes" (Doniger, 1991, p. 505). Pan is symbolic of how trauma splits the psyche into complexes, but he also symbolizes how to remain vulnerable and open to the diversities in ourselves, even the monstrous parts. This choice leads to greater tolerance of diversity in others, in the natural world, and in understandings of the divine. 


\section{Fontelieu}

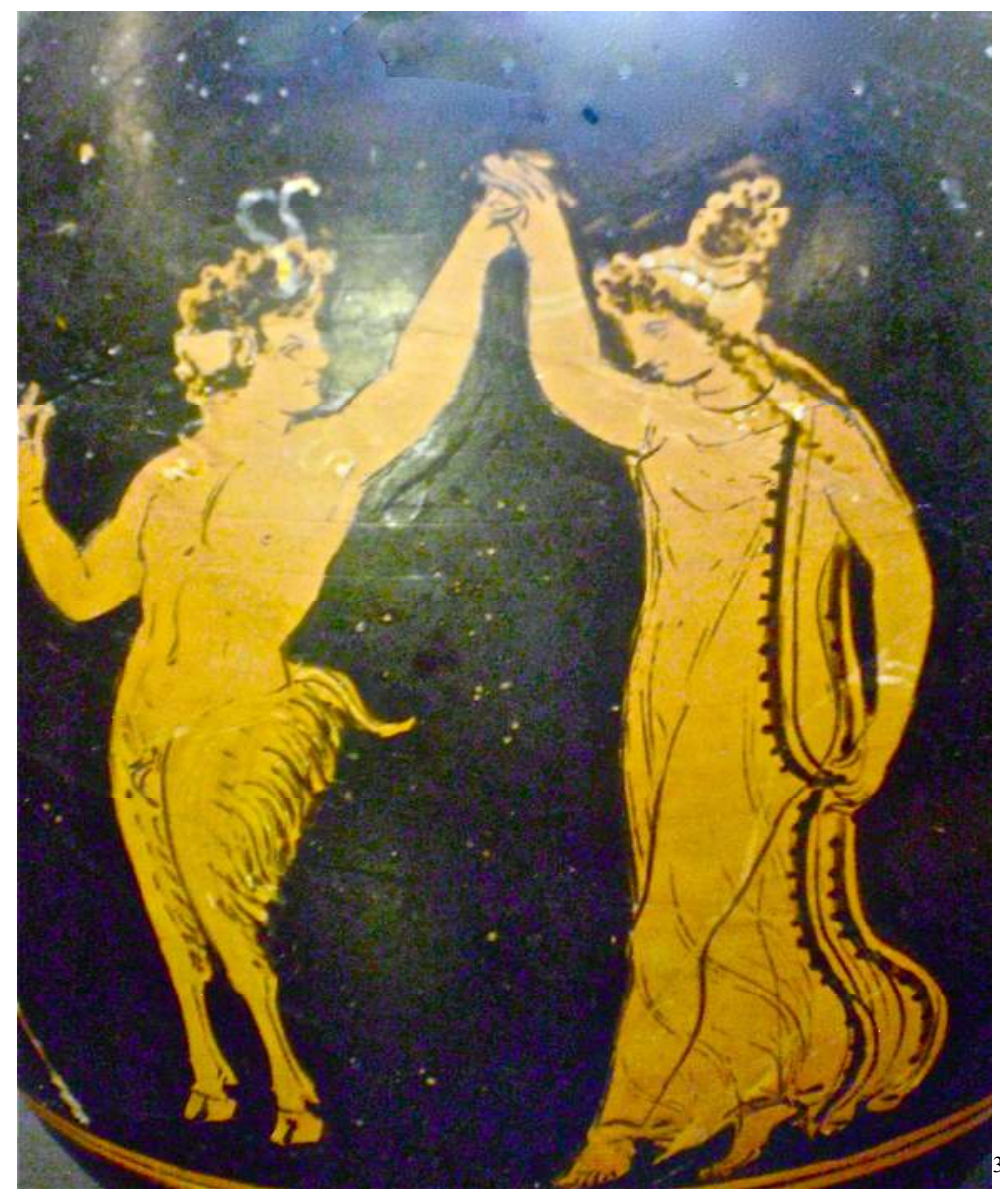

Figure 4. Aegipan dancing with Echo. Red figure olpe attributed to The Underworld Painter. 330-310 BCE. British Museum: London, England. (C) Trustees of the British Museum.

In one version from antiquity the nymph Syrinx does not remain stuck; forever a reed. She evolves to an even freer state than she was as a naiad of the River Ladon. In Nonnos, a Greek epic poet of the fifth or sixth century, Syrinx lived on as one of the Bakhoi (1940/1062). After the panic she devolved to a vegetative state, but in this telling, Syrinx regained her freedom of speech and movement and then gained sexual freedom as well. She became a nymph in Dionysus' retinue. "Syrinx escaped from Pan's marriage and left him without a bride, and now she cries euoi to the newly-made marriage of Dionysos" (Nonnos, 1940/1962, p. 27 [XVI. 330-334]). In the ancient Bacchic revels, euoi (pronounced you-oh-ee) is a cry of impassioned rapture (Morwood \& Taylor, 2002, p. 144).

She did not remain buried in the earth nor did she return as a virginal nymph. She was transformed into a feminine being with the right to choose her partner. In 


\section{Journal of Jungian Scholarly Studies 20}

the myth, emphasis is placed on her having a voice and sexual freedom (Nonnos, 1940/1962). She was able to enjoy running in states of impassioned rapture rather than running in a state of panic. The same story suggests that when the unmitigated phallic power, represented by Pan, experienced a vulnerable state of sadness and discovered a way to sublimate his frustration and sadness through music, the life giving nymph Syrinx was able to evolve rather than remaining frozen in a vegetative state. When the cacophony of echoes and wails of the nymphs and the pent up aggressions of Pan were transformed the result was music and rapture.

The American government, as the dominant power in the country in matters of international affairs, failed in any way to inspire the country to carry consciously the suffering caused by the terrible losses on $9 / 11$. Instead of the government taking responsibility for having failed its people, it treated the public more like children. It is difficult to ignore the irony in Bush's reading The Pet Goat (Englemann \& Bruner, 1995) (which he was inadvertently holding upside down) to kindergarten children when the first plane flew into the first tower. Military might and grandiose visions of a "Citty upon a hill," once seemingly invincible, are now a drag on America's future. Perhaps a lesson can taken from the nymphs, who were able to hold Pan's power and inflated tendencies in check when they grouped together to laugh, dance, and play in harmony with him. They did not exclude him, they even let him lead, but the relational kindness of those beautiful beings was able to subdue the strongest force in their universe, the Pan of nature (one meaning of the Greek pan is all), when they joined together. Perhaps, the antidote to an inflated vision of exceptionalism can emerge, as in Syrinx's story, when the aggressive forces in American culture begin to express their vulnerability rather then their might.

Currently the worst of the Pan archetype underlies a cultural complex, like an emotional disorder within the country. The US is faced with problems that are irresolvable from within this complex. Fortunately, an activated complex has greater potential to become conscious, and so containable, than when one is wholly in the unconscious; in the case of a cultural complex, if that process is to succeed, it will happen in individuals one by one (Kimbles, 2000).

Perhaps, the first step is to recognize the real and immediate fallout from faulty cultural concepts such as exceptionalism for modernity, next to ferret out the ways these concepts have unconsciously infected one's own psyche, and then to intuit how rejection of them can inspire the culture. The creative arts, and especially film, come to my mind as the vehicle through which contemporary society asserts the symbolic life of the culture, which "consists of traditional (i.e., historically derived and selected) ideas and especially their attached values" (Kroeber \& Kluckhorn, 1952, p. 181). So much of current popular film expresses the adoration of the hypermasculine Pan archetype and how it symbolizes American strength. 


\section{Fontelieu}

Jungian analyst Andrew Samuels (1993) considers that "the characteristic of late modernity to try to make use of knowledge about itself can be recast as a struggle within our culture to become self-conscious; our culture struggles to become psychological" (p. 8). Kimbles (2003) suggests that awareness of cultural complexes might allow for "the creation of a narrating third, a space for symbolization, and the possibility of reflection .... The existence of cultural complexes opens the possibility that as a collective we might be able to do a therapeutic type of cultural analysis" (p. 232). A culture that is ready to become more conscious of itself can readily see that acts of terror are continuing to lead to acts of terror and that walls of military defense or naive nosedives into escapism are not working. Pan's aggression is symbolically contained through group ritual, and this suggests that the aggression in exceptionalism could be contained through group participation as well.

The expansive impulses, once alive in the bold spirit of the European colonists of America, have grown rusty and settled into a paralysis and fear of initiative towards contemporary American problems. This pattern is mirrored by American reactions to $9 / 11$ and channels problems toward certain predicable results. Radical Islamists imitate American aggression and dominate using military cunning. The bullied becomes the bully. This pattern causes cultural complexes to multiply and like cogs in a cogwheel, force each other along in a lockstep of what appear to be inevitable, negative outcomes.

The US could get out ahead of the inevitable fall that the inflation of exceptionalism, according to Jung's understanding of compensation, will engender. Exactly how to go about that needs to be a debate in which depth psychologists contribute by attempting to articulate the shadow sides of the American culture. It is not difficult to see the results of the shadow - now is the time to see into the underlying cultural beliefs that are unconsciously creating Pan's "confusion and tumult" (Artemidorus, 1975, p. 118), and to intuit how the soothing, healing nature of the nymphs might emerge. Now is the time for depth psychologists to reflect on their responsibilities, not only to the problems of the individual psyche, but also to the shadow problems created by groups.

\section{References}

Aaron, D. (2008). In their own words: Voices of Jihad. Santa Monica, CA: Rand.

American Psychiatric Association. (2013). Diagnostic and statistical manual of mental disorders $\left(5^{\text {th }}\right.$ ed.). Washington, DC: Author.

Arndt, J., Solomon, S., Kasser, T., \& Sheldon, K. (2004). The urge to splurge: A terror management account of materialism and consumer behavior. Journal of Consumer Psychology (Lawrence Erlbaum Associates), 14, 198-212. doi:10.1207/s15327663jcp1403_2

Aristophanes. (2000). Birds-Lysistrata-Women at the Thesmophoria. (J. Henderson, Trans.). Cambridge, MA: Harvard University Press. 


\section{Journal of Jungian Scholarly Studies 22}

Artemidorus. (1975). The interpretation of dreams: Oneirocritica. (R. J. White, Trans.). Park Ridge, NJ: Noyes Press.

Barak, G. (2005). A reciprocal approach to peacemaking criminology: Between adversarialism and mutualism. American Behavioral Scientist, 9, 131-152. doi: 10.1177/1362480605051640

BBC News. (2004, Sept. 16). Iraq war illegal, says Annan. Retrieved from http://bbc.co.uk/2/hi/36611 34.stm

Bernstein, N. (2006, April 3). 9/11 detainees in New Jersey say they were abused with dogs. The New York Times. Retrieved from http://nytimes.com/2006/04/03/nyregion/03detain.html?page wanted=alls

Boardman, J. (1997). The great god Pan: The survival of an image. New York, NY: Thames and Hudson.

Boer, C. Trans. (1970). The Homeric hymns (Rev. $2^{\text {nd }}$ Ver.). Woodstock, CT: Spring.

Borgeaud, P. (1988). The cult of Pan. (K. Atlass \& J. Redfield, Trans.). Chicago, IL: University of Chicago Press. (Original work published 1979)

Bulfinch, T. (1855). The age of fables or stories of gods and heroes. Boston, MA: Sanborn, Carter, \& Bazin.

Bush, G. (2001a, September 11). Address to the American public. Retrieved from http://georgewawhitehouse.archives.gov/news/releases/2001/09/20010911-16.html

Bush, G. (2001b, September 16). Bush talks about Crusade on Sept 16-2001. Retrieved from http://youtube.com/watch?v=NsjgjM56HRw

Bush, G. (2001c, September 21). At O'Hare, President says “Get on board.” Retrieved from http://georgewbush-whitehouse.archives.gov/news/releases/2001/09/20010927-1.html

Bush, G. (2002, January 29). Text of President Bush's 2002 state of the union address. The Washington Post. Retrieved from http://www.washingtonpost.com/wpsrv/onpolitics/transcripts/sou012902.htm

Bush, G. (2003, September 7). President George W. Bush: Update in the war on terror. Retrieved from http://www.911memorial.org/sites/all/files/President\%20Bush's\%20update\%20in\% 20the \%20war\%20on\%20terror.pdf

Cassaliggi, J. (2013). Retrieved from http://www.youtube.com/watch?v=eSueQsVsk_M

Clarke, R. (2004). Against all enemies: Inside America's war on terror. New York, NY: Free Press.

Clarke, R., \& Newman, G. (2006). Outsmarting the terrorists. Westport, CT: Greenwood Publishing Group.

Cohen, D. (1998). Culture, social organization, and patterns of violence. Journal of Personality and Social Psychology, 75, 408-419. doi: 10.1037/0022-3514.75.2.408

Cohen, P., Kasen, S., Chen, H., Gordon, K., Berenson, K, Brook, J, \& White, T. (2006). Current affairs and the public psyche: American anxiety in the post 9/11 world. Social Psychiatry and Psychiatric Epidemiology, 41, 251-260. doi: 10.1007/s00127-006-0033-7

Colvin, G. (2001). The cost of complacency. Fortune, 144(6), 50. Retrieved from http://web.ebscohost.com.pgi.idm.oclc.org/ehost/detail

David, C-P., \& Grondin, D. (2006). Hegemony or empire: The redefinition of US power under George W. Bush. Hampshire, England: Ashgate Publishing.

Dioscorides. (1959). In R. T. Gunther (Ed.), The Greek herbal of Dioscorides: Materiamedica (J. Goodyer, Trans.). New York, NY: Hafner Publishing. (Original work published 1934)

Doniger, W. (1991). Mythologies. Vol. 1. (Trans. G. Honigsblum). Chicago, IL: University of Chicago Press. 


\section{Fontelieu}

Edmonds, J. M. Trans. (1977). Moschus. The Greek bucolic poets (pp. 459-461). Cambridge, MA: Harvard University Press. (Original work published 1912)

Eliade, M. (Ed.). (1987). The encyclopedia of religion (Vol. 11). New York, NY: MacMillan Publishing.

Engelmann, S., \& Bruner, E. (1995). Reading Mastery II: Storybook 1 (Rainbow ed.). Worthington, OH: SRA Macmillan/McGraw-Hill. Retrieved from http://dictionary.sensagent.com/ Pet\%20Goat/en-en/

Erikson, E. (1994). Identity and the life cycle. New York, NY: Norton.

Farnell, L. R. (1971). The cults of the Greek states (Vol. 5). Chicago, IL: Aegaean Press. (Original work published 1909)

FinCEN. (2012). USA Patriot Act. Retrieved from http://fincen.gov/statutes_regs/patriot/index.html

Flaccus, G. V. (1963). Argonautica. (J. J. Mozley, Trans.). Cambridge, MA: Harvard University Press. (Original work published 1934)

Furedi, F. (2007) Invitation to terror: The expanding empire of the unknown. London, England: Continuum.

Furr, G. (2001, November, 9-11). Seeking opposition to the war. Counterpunch. Retrieved from http://www.counterpunch.org/2001/11/09/seeking-opposition-to-the-war/

Galea, S., Ahern, J., Resnick, H., Kilpatrick, D., Bucuvalas, M., Gold, J., \& Vlahov, D. (2002). Psychological sequaelae of the September 11 terrorist attacks in New York City. New England Journal of Medicine, 346(13), 982-987. Abstract retrieved from http://www.ncbi.nlm.nih.gov/pubmed/11919308

Glick, P., Fiske, S., Abrams, D., Dardenne, B., Ferreira, M., Gonzalez, R., ....Yzerbyt, V. (2006). Anti-American sentiment and America's perceived intent to dominate: An 11-nation study. Basic and Applied Social Psychology, 28, 363-373. doi:10.1207/s15324834basp2804_10

Guthrie, W. (2011). This land is your land. Retrieved from http://woodyguthrie.org/Lyrics/This_Land. htm

Health Information Privacy. (2012). Health information privacy. Washington DC: US Department of Health \& Human Services. Retrieved from http://www.hhs.gov/ocr/privacy

Henderson, J. (1984). Cultural attitudes in psychological perspectives. Toronto, Canada: Inner City Books.

Herodotus. (1960). Herodotus. (A.D. Godley, Trans.) (Vol 1). London, England: William Heinemann. (Original work published 1921)

Hillman, J. (1988). Pan and the nightmare. Dallas, TX: Spring.

Hippel, von K. (2002, August). The roots of terrorism: Probing the myths. The Political Quarterly, 73(1), 25-39. Retrieved from http://web.ebscohost.com.pgi.idm.oclc.org/ehost/detail

Hodgson, G. (2009). The myth of American exceptionalism. New Haven, CT: Yale University Press.

Irish, M. (2002). Making us stronger. Journal of financial planning, 15(9), 10. Retrieved from http://web.ebscohost.com.pgi.idm.oclc.org/ehost/detail

Jahoda, G. (2012). Critical reflections on some recent definitions of "culture." Culture \& Psychology, 18, 289-303. doi: 10.1177/1354067X12446229

Joyce, J. (1961). Ulysses. New York, NY: Random House.

Jung, C. G. (1959a). The psychology of the child archetype. In H. Read et al. (Eds.), The collected works of C. G. Jung (R. F. C. Hull, Trans.) (Vol. 9i, pp. 150-181). Princeton, NJ: Princeton University Press. (Original work published 1951) 


\section{Journal of Jungian Scholarly Studies 24}

Jung, C. G. (1959b). The shadow. In H. Read et al. (Eds.), The collected works of C. G. Jung (R. F. C. Hull, Trans.) (Vol. 9ii, pp. 8-10). Princeton, NJ: Princeton University Press. (Original work published 1951)

Jung, C. G. (1960). A review of complex theory. In H. Read et al. (Eds.), The collected works of C. G. Jung (R. F. C. Hull, Trans.) (Vol. 8, pp. 92-106). Princeton, NJ: Princeton University Press. (Original work published 1948)

Jung, C. G. (1967). The Spirit Mercurius. In H. Read et al. (Eds.) (Trans. R.F.C. Hull), The collected works of C. G. Jung. (Vol. 13, pp. 191-250). Princeton, NJ: Princeton University Press. (Original work published 1948)

Jung, C. G. (1978). The fight with the shadow. In H. Read et al. (Eds.) The collected works of C. G. Jung. (R. F. C. Hull, Trans.) (Vol. 10, pp. 218-226). Princeton, NJ: Princeton University Press. (Original work published 1946)

Kerenyi, C. (1998). The gods of the Greeks. London, England: Thames and Hudson.

Kimbles, S. (2000). The cultural complex and the myth of invisibility. In The vision thing: Myth, politics and psyche in the world (pp. 155-169). London, England: Routledge.

Kimbles, S. (2003). Cultural complexes and the collective shadow process. In J. Beebe (Ed.), Terror, violence and the impulse to destroy: Perspectives from analytical psychology (pp. 211234). Einsiedeln, Switzerland: DaimonVerlag.

Kroeber, A. L., \& Kluckhohn, C. (1952). Culture: A critical review of concepts and definitions. Cambridge, MA: Peabody Museum of American archæology and ethnology, Harvard University.

Krugman, P. (2011, January, 10). Climate of hate. The New York Times, A19.

Kugler, M. B., \& Cooper, J. (2010). Still an American? Mortality salience and treatment of suspected terrorists. Journal of Applied Social Psychology, 40(12), 3130-3147. Retrieved from http://web.ebscohost.com.pgi.idm.oclc.org/ehost/resultsadvanced

Larson, B. J. (2001). Greek nymphs: Myth, cult, lore. Oxford, England: Oxford University Press.

Lifton, R. J. (2003). Super power syndrome: America's apocalyptic confrontation with the world. New York, NY: Thunder's Mouth Press/ Nation Books.

Lincoln, A. (1862, December, 1). Annual message to Congress: Concluding remarks. http://www.abrahamlincolnonline.org/lincoln/speeches/congress.html

Longus. (1978). Daphnis and Chloe. (G. Thornley, Trans. \& Rev. by J. M. Edmonds). London, England: William Heinemann. (Original work published 1916)

Lu, K. (2013). Can individual psychology explain social phenomena? An appraisal of the theory of cultural complexes. Psychoanalysis, Culture \& Society. 18(4), 386-404. doi: $10.1057 /$ pcs.2013.18

Lucy, J. (2003, February 1). On the scene at the WTC. Electrical Wholesaling. Retrieved from http://ewweb.com/news-watch/scene-wtc

Marshall, R. D., \& Galea, S. (2004). Science for the community: Assessing mental health after 9/11. Journal of Clinical Psychiatry, 65 (Suppl. 1), 37-43. Abstract retrieved from http://psycnet.apa.org.pgi.idm.oclc.org/psycinfo/2004-10639-005.

Meyer, R. (Director). (2005). The great Indian wars. Centre Communications for BCI, A Navarre Corporation (Producer) (3 DVDs). Minneapolis, MN: Navarre.

Moore, M. (2002). Bowling for Columbine. K. Glynn, \& J. Czarnecki, Prod. [Motion Picture] MGM.

Morwood, J. \& Taylor, J. (2002). The pocket Oxford classical Greek dictionary. Oxford, England: Oxford University Press.

Moustakas, C. (1994). Phenomenological research methods. Thousand Oaks, CA: Sage. 


\section{Fontelieu}

Mueller, J. (2005). Simplicity and spook: Terrorism and the dynamics of threat exaggeration. International Studies Perspectives, 6(2), 208-234. Retrieved from doi: 10.1111/j.15283577.2005.00203x

Nonnos. (1962). Dionysiaca. (Vol. II.) (W.H.D. Rouse, Trans.). London, England: William Heinemann. (Original work published 1940)

Obama, B. (2014, May 28). Transcript of President Obama's commencement address at West Point. New York Times. Retrieved from http://www.nytimes.com/2014/05/29/us/politics/transcriptof-president-obamas-commencement-address-at-west-point.html

Office of Homeland Security. (2002). The national strategy for homeland security. Washington DC. Retrieved from http://www.dhs.gov/xlibrary/assets/nat_strat_hls.pdf

Osborn C., Johnson B., \& Fisher J. (2006). After 9/11 at ground zero: The anxiety-buffering effects of worldview support on the first anniversary of 9/11. Basic and Applied Social Psychology, 28, 303-310. doi: 10.1207/s15324834basp2804_3

Ovid. (1986). The metamorphoses of Ovid. (Mary M. Innes, Trans.). Middlesex, England: Penguin. (Original work published 1955)

Pausanias. (1961). Pausanias: Description of Greece. (Vol. IV) (W. H. S. Jones, Trans.). Cambridge, MA: Harvard University Press. (Original work published 1935)

Perera, S. B. (1986). The scapegoat complex: Toward a mythology of shadow and guilt. Toronto, Canada: Inner City Books.

Perry, J. W. (1970). Emotions and object relations. Journal of Analytical Psychology, 15, 1-12. Retrieved from http://web.a.ebscohost.com.pgi.idm.oclc.org/ehost/detail

Pfaff, W. (2007, February 15). Manifest destiny: A new direction for America. The New York review of books. Retrieved from http://www.nybooks.com/articles/archives/2007/feb/15/manifestdestiny-a-new-direction-for-america/

Philostratus. (1960). Imagines. (A. Fairbanks, Trans.). London, England: William Heinemann. (Original work published 1931)

Plutarch. (2003). Isis and Osiris. Moralia. (F. C. Babbitt, Trans.) (Vol. 5, pp. 6-191). Cambridge, MA: Harvard University Press. (Original work published 1936)

Polyaenus. (1994). Stratagems of war. (P. Krentz \& E. L. Wheeler, Eds. \& Trans.) (Vol. I). Chicago, IL: Ares Publisher.

Pyszczynski, T., Solomon, S., \& Greenberg, J. (2003). In the wake of 9/11: The psychology of terror. Washington, DC: American Psychological Association.

Richey, W., \& Feldmann, L. (2003, September 12). Has post-9/11 dragnet gone too far? Christian Science Monitor, 95(202), 1.Retrieved from http://web.ebscohost.com.pgi.idm.oclc.org/ehost/resultsadvanced

Rumsfeld, D. (2006). Retrieved from http://www.youtube.com/watch? $v=$ RpSv3HjpEw

Samuels, A. (1993). The political psyche. London, England: Routledge.

Samuels, A., Shorter, B., \& Plaut, F. (2005). A critical dictionary of Jungian analysis. London: Routledge.

Segal, C. P. (1969). Landscape in Ovid's Metamorphoses: A study in the transformations of a literary symbol. Wiesbaden, Germany: Franz Steiner Verlag GMBH.

Shahshahani, A. (2011). Reflections on the occasion of the tenth anniversary of September 11. Race/Ethnicity: Multidisciplinary Global Perspectives, 4(3), 449-454, Retrieved from http://muse.jhu.edu/results\#type=ajax\&startYear=\&stopYear=\&limits=subscription:Y\&ter $\mathrm{ms}=$ content:Reflections $\% 20$ occasion $\% 20$ tenth\%20anniversary\%20September. 


\section{Journal of Jungian Scholarly Studies 26}

Singer, T. (2004). The cultural complex and archetypal defenses of the group spirit: Baby Zeus, Elian Gonzales, Constantine's Sword, and other holy wars (with special attention to the "axis of evil"). In (T. Singer \& S. Kimbles, Eds.), The cultural complex: Contemporary Jungian perspectives on psyche and society (pp. 13-34). Hove, England: Brunner-Routledge.

Singer, T., \& Kimbles, S. (2004). Introduction. In (T. Singer \& S. Kimbles, Eds.), The cultural complex: Contemporary Jungian perspectives on psyche and society (pp. 1-9). Hove, England: Brunner-Routledge.

Sipri. (2014). SIPRI military expenditure database. Retrieved from http://milexdata.sipri.org/files/?file=SIPRI+military+expenditure+database+1988-2013.xlsx

Slovenko, R. (2005). Euphemisms. Journal of Psychiatry \& Law, 33(4), 533-548. Retrieved from http://web.ebscohost.com.pgi.idm.oclc.org/ehost/pdfviewer

Smith, S. F. (2011). My country tis of thee. Retrieved from http://www.cyberhymnal.org/bio/s/m/i/ smith_sf.htm

Stein, M. (1995). Introduction. In Jung and evil (pp. 1-24). Princeton, NJ: Princeton University Press.

Swiney, C. (2006). Racial profiling of Arabs and Muslims in the US: Historical, empirical, and legal analysis applied to the war on terrorism. Muslim World Journal of Human Rights, 3(1), 1053. Retrieved from http://www.degruyter.com/view/j/mwjhr.2006.3.1/mwjhr.2006.3.1.10 53/mwjhr.2006.3.1.1053.xml.

Tatius, A. (1969). Achilles Tatius (S. Gaselee, Trans.). London, England: William Heinemann. (Original work published 1917)

Theocritus. (1999). In R. Hunter(Ed.), Theocritus: A Selection: Idylls 1, 3, 6, 7, 10, 11 and 13. Cambridge, MA: Cambridge University Press.

de Tocqueville, A. (1840). Democracy in America: Part second: The social influence of democracy. New York, NY: J. \& H. G. Langley.

Venn, C. (2002). World dis/order: On some fundamental questions. Theory, Culture and Society, 19, 121-136. doi: 10.1177/0263276402019004009

Wood, G. (2011). The idea of America: Reflections on the birth of the United States. New York, NY: Penguin.

Woodward, B. (2004). Plan of attack. New York, NY: Simon \& Schuster.

World Press Review. (2012). The United Nations, international law, and the war in Iraq. Retrieved from http://worldpress.org/specials/iraq

Zero tolerance. (2012). Information regarding zero tolerance for firearms in schools. California Department of Education. Retrieved from http://www.cde.ca.gov/ls/ss/se/zerotolerance.asp

Zuckerman, S. (2002, September 8). 9-11-01: Impact on business; American consumers kept economy going. The San Francisco Chronicle, G1. Retrieved from http://www.sfgate.com/cgi-bin/article.cgi?f=/c/a/2002/09/08/BU1537.DTL

\section{Notes}

\footnotetext{
${ }^{1}$ Though some of the categories in the DSM-5 are controversial and it has not resolved problems of reliability in diagnosing (Spiegel, 2005, p. 63), its compounded lists of symptoms for psychological disorders are accepted as accurate within the American field of psychology and psychiatry (APA, 2013).

2 An estimated 500,000 Iraqi children's deaths were the "collateral damage" during Operation Desert Storm and the economic sanctions against Iraq (Perice, 2006, p. 121). In an interview in 1996, Leslie Stahl asked then Secretary of State Madeleine Albright:
} 


\section{Fontelieu}

Stahl: "We have heard that a half-million children have died. I mean, that's more children than died in Hiroshima. And you know, is the price worth it?"

Albright: "I think it is a very hard choice, but the price ... we think the price is worth it" (as cited in Perice, 2006, p. 121). 